\title{
Institutions of Confinement as Sites of Passage
}

The Mètis of Foreign Nationals Caught in the Wars on Terror, Drugs and Immigration

Carolina S. Boe, Aarhus University and Université de Paris

\begin{abstract}
Never have so many foreign nationals been confined and deported from Europe and the USA as within the past decades. Yet a minority succeeds in remaining undeported for years and sometimes decades, in spite of being targets of enforcement practices related to the wars on drugs, on terror and on immigration. As they are brought into forced circulations between prisons, detention centres and the public spaces of penalized neigborhoods, they join a 'floating population' of exiles, transforming spaces of confinement into sites of passage. Drawing on ethnographic fieldwork and biographical interviews at different moments of the trajectories of 'the undeported', this article examines how their ability to avoid deportation develops and increases. The notion of mètis is mobilized to analyse how individuals adapt tactically or strategically to shifting, uncertain situations, and to understand the changes that they can sometimes bring to bear on the larger social forces that constrain them.
\end{abstract}

Keywords: confinement, drug laws, immigration detention, immigration laws, mètis, penalized neighbourhoods, prison, terror laws, social navigation

Prison of Fresnes, France, November 2003. I'm standing in front of the lawyers' visiting cell, waiting for my next appointment. 'Madame Carolina! How are you doing?' I turn my head towards a familiar voice and look bewildered at his emaciated face for a bit too long before I recognize 'Rachid'. ${ }^{1}$ He reads my thoughts, smiles and says:

Yes, I'm still alive. And I wrote to my sister when I got here last night. When I heard that it was Thursday, I was hoping to see you here, do you have time to see me later today? 
I smile back at him, 'Of course! Right after this appointment. Good news, the reform on deportation was just voted into law. We should be able to get your deportation order cancelled'. He thanks me and shakes my hand warmly, and I feel the bones beneath the paper-thin skin of his skinny hand. As saddened as I am to see him back in prison, I am relieved that he is still alive. Until now, with the new reform, French immigration law has offered no possibilities for relief, and Rachid's strategy to avoid deportation is self-mutilating. After his latest release from prison, Rachid called me from the hospital where he was recovering after having swallowed a fork at the immigration detention centre a few hours prior to being taken to the airport. A few weeks later, I bumped into his sister in the neighbourhood in which we were both living, a few blocks from the housing estate where they had grown up. Now that Rachid had been released from the hospital to the street, she worried that he was back at the Stalingrad métro station, where street-level drug users then gathered around heroin and crack cocaine. His sister and I both knew that the biggest percentage of overdoses on the streets are among drug users who shoot up after a prison-induced abstinence, which is why I am relieved to see him, even behind bars. Rachid turns away from me to go back to the prisoners' waiting cell, and I watch him as he walks down the hallway. A frail demeanour, after four months on the streets, but he confidently greets guards, who recognize him from previous incarcerations, as well as fellow prisoners, many of whom are old friends from his neighbourhood. This prison may be the second largest in France, holding some two thousand prisoners at a time, but many of them enter and exit its gates in what Manuela da Cunha (2008) has called a 'closed circuit' between penalized neighbourhoods and prisons.

In Rachid's case, as in that of other foreign national citizens, the 'closed circuit' however involves other spaces besides his neighbourhood and the prison, as he is also routinely confined in immigration detention centres. He belongs to the 1.5 generation, who migrated with their first-generation immigrant parents when they were children, but who do not hold citizenship in the country in which they grew up and were socialized (Boe 2016). As a consequence, they can be ordered deported.

During the past three decades, due to changes in legislation, the 'social worlds' of penalized neighbourhoods of the global north have increasingly poured out to new locations in the global south, when their inhabitants have been deported to their countries of citizenship (Brotherton and Barrios 2011; Coutin 2016; De Genova and Peutz 2010; Dingeman-Cerda and Rumbaut 2015 Zilberg 2011). The scope of this article differs from these studies with its specific focus on the 'undeported', who manage to stay in France or the USA in spite of a deportation order and who become part of a 'floating population' (Foucault 1979) of exiles who routinely 'traverse sites of confinement' (Jefferson 2010: 387). These sites have been created or re-enforced during the combined wars against drugs, immigration and terror, in France and the USA. Though there are differences between the immigration law and criminal justice systems in these two countries (Boe 2009), I will focus on some of the similarities between their effects, specifically for foreign nationals who, 
like Rachid, were caught up in the laws of the 1980s and 1990s against substance abuse and trade in poorer neighbourhoods (Bourgois 2002; Kokoreff, Coppel and Peraldi 2018).

The article draws on ethnographic non-consecutive fieldwork and biographical interviews with (former) foreign national prisoners carried out in the greater New York Area and the Paris region since 2002 (Boe 2009, 2016; Boe and Fischer 2010), and owes much to my experiences as a paralegal lawyer, a translator and a resident of neighbourhoods that hold many deportees. My involvement defending foreign national prisoners who were in deportation proceedings from France in the early 2000s was initially inspired by meeting deportees in the neighbourhoods of Flatbush and Jackson Heights, New York. I have since remained involved as an activist, friend and researcher in both sites, but especially in Paris, where I live. Working as a paralegal immigration lawyer in prison gave me two insights which I will discuss in this article. First, both prison and deportation are, in principle, supposed to be one-time occurrences. Yet I kept meeting the same men and women, over and over again, who were routinely re-incarcerated and released, after the administration's failed attempts to deport them. Their multiple incarcerations spurred successive deportation orders, which, in turn, led to new incarcerations related to immigration offences. Often, they got to know one another, as they did the staff and the routines of the detention centres and prisons, and, like Rachid, they remembered that Thursday was the day that the non-profit immigration lawyer was in the house. Second, my position as a paralegal immigration lawyer deemed to be an outsider to the prison administration and an advocate against deportation 'on their side' gave me access to some of the unofficial practices that prison staff often suspect from prisoners who comply outwardly with regulations, but which are rarely fully disclosed to them.

In the following, I will discuss the ways in which anthropologists of confinement have analysed power relations within sites of confinement and their relationship to the pre-carceral experiences of prisoners from penalized neighbourhoods. I will then analyse the ways in which forms of knowledge about how to engage in power relations, which were acquired or developed in one site of confinement, are mobilized in others and how they travel between sites through the trajectories of foreign nationals who are brought into forced circulations between prisons, detention centres and their neighbourhoods. Here, I will discuss the ways in which they can, sometimes, change and improve the situations of the 'undeported. The sailing metaphor and the term 'social navigation' refer to the action of moving tactically in relation to social forces that confine, push or pull agents and convey the ways in which individuals act in difficult, unstable or uncertain circumstances to disentangle themselves from confining structures, plot their escape and move towards better positions (Vigh 2010). As Henrik Vigh also points out, however, 'social navigation' is often used in unspecified ways.

What I wish to suggest here is to mobilize the distinction between mètis (cunning, adaptability) and bie (brute force) (Détienne and Vernant 1974; Scott 1998), which makes it possible to distinguish between two different ways of reacting 
to new situations. The ancient Greek used the term mètis to convey the sorts of practical skills and acquired intelligence that subjects develop when fighting against a stronger adversary and responding to a constantly changing natural or human environment. Mètis is the opposite of bie, and is 'variously called know-how (savoirfaire or arts de faire), common sense, experience, a knack' (Scott 1998: 311). As James Scott states: 'All human activities require a considerable degree of mètis, but some activities require far more' (ibid.: 313). Among these, I argue that the experiences of prisons and detention centres, and the avoidance of deportation, require much mètis.

\section{Daniel's closed circuit: Bed-Stuy - Kuwait - Bed-Stuy - Rikers Island}

'Daniel' and I met at an anti-deportation rally in Lower Manhattan in 2007 where he spoke publicly for the first time, along with other members of the community organization Families For Freedom. Like many recently released immigration detainees and prisoners, stories of his incarcerations and detentions were easily triggered, and as I liked to listen to them they flowed in a steady stream in a broad Brooklynite accent, ranging from funny anecdotes from his childhood in Bed-Stuy and early army days to brutal tales of Operation Desert Storm, incarceration in Rikers Island, immigration detention at FDC Oakdale, in Louisiana, and life as a drug user on the streets of New York. Over the coming years, I formally interviewed Daniel extensively and spent time with him in his neighbourhood. Daniel had left his native Trinidad in his early teens to join his family in the Brooklyn neighbourhood of Bed-Stuy, in New York. Unlike many of his neighbourhood friends, growing up, Daniel had 'stayed away from trouble', and had been a 'passive type', as he expresses it. He joined the army aged seventeen, when a recruiter approached him in the parking lot of his Brooklyn high school and promised him US citizenship and better vocational and educational possibilities than Bed-Stuy could offer.

Eight years and Operation Desert Storm later, Daniel was honourably discharged from the US army with several medals and post-traumatic stress disorder. He found ways of soothing his anxieties with old friends from his neighbourhood who had got into crack cocaine. His new addiction soon brought him to Rikers Island, the biggest penal colony in the world, located close to New York City. Like many other drug users, and similarly to Rachid from Paris, Daniel from Bed-Stuy entered a 'downward spiral' (Chantraine 2004; Contreras 2012; Duprez and Kokoreff 2000) of substance abuse, homelessness and successive incarcerations for possession of controlled substances with intent to use or intent to sell, petty thefts and, several times, turnstile jumping. His grandmother and aunt often tried to help him, bailing him out, letting him sleep in their homes and offering moral support. Between incarcerations, Daniel, who identified strongly with the neighbourhood he had grown up in, always returned to Bed-Stuy, living in squatted houses, in Prospect Park or on the streets, where he, like many other drug users, was made 'police property' (Jobard 2010; Lee 1981) and was easily picked up for arrest and incarceration. 
When immigration officers approached Daniel at the end of one of his prison sentences, he first thought that there was a misunderstanding. As he understood that he had been ordered deported from the US, Daniel discovered that not only had the army recruiters' promise of better vocational opportunities not been honoured, but in spite of eight years in the service, he had in fact not become a US citizen. Daniel was ordered deported due to laws passed in the aftermath of the Oklahoma bombings in 1995. When the 1996 laws were signed by President Clinton, it was already known that the Oklahoma bombings had been carried out by a white US citizen Gulf War veteran, Timothy McVeigh. However, the 1996 laws expanded the grounds on which foreign nationals could be deported and retroactively transformed great numbers of permanent legal residents, who had a criminal record, into illegalized, and deportable, 'criminal aliens' overnight, often years or even decades after they had served their sentence. Possession of marijuana, shoplifting, theft, writing a bad cheque, battery, jumping a subway turnstile without paying a fare, and even hair pulling became criminal grounds for deportation (Morawetz 2000). Most deportable 'criminal aliens' had been sentenced for drug- or poverty-related misdemeanours during the 'wars on crime,' 'wars on drugs' and 'zero tolerance' measures of the 1980s and 1990s, and the War on Terror in the aftermath of $9 / 11$ brought increased enforcement of these measures.

Daniel told me how, growing up, he had never expected to go to prison. He was much more scared than fascinated by what he had heard of Rikers Island from childhood friends who had been incarcerated there, in contrast to friends from his neighbourhood who had considered prison as something inevitable, as a feared yet wanted 'rite of passage' (Boe 2016, 2018). In 2007, when I first interviewed Daniel and asked him what he had known about prison before his first incarceration, he answered:

The name for Rikers Island was Gladiator school, you know. You go there... if you don't fight, you know, you're dead, basically. You know, maybe not literally, but figuratively. ... You hadda fight to survive, you know. ... And you hear the stories from guys coming outta there, you know, friends that you know, you know, guys that you went to school with. All of a sudden you see them one day and they got a scar, running from the top of their head to the bottom of their face.... Those, you know, those stories always stuck on me. Cause at my young age, I was no troublemaker or big fighter. I was always a passive type, you know what I'm saying? Stayed by myself, stayed away from trouble. So hearing those stories, Rikers Island - for me - at that time, Rikers Island was my greatest fear... in life! Period.

Though Daniel was incarcerated for the first time when he was in his mid twenties, having only recently started buying and consuming drugs in his neighbourhood, he knew from the experience of childhood friends how to blend in with other prisoners from marginalized neighbourhoods similar to his own. Like other men and women I met in France and the US who had never been imprisoned before, but who had grown up in penalized neighbourhoods, he had acquired knowledge about the functioning of the institution from his peers who had prepared him and taught him the ropes of prison life (Boe 2016). 
On his first day at Rikers Island, Daniel searched out the company of acquaintances from his neighbourhood who would accept him as a member of their peer group, and he eventually joined the ñetas, a prison gang. When I first interviewed Daniel in 2007, he spoke enthusiastically about his decade-long membership of the ñetas, which had helped him through the use of force and confrontation, of bie, as he faced the house-gangs of Rikers Island that controlled access to the phones and many other goods within the prison. Though Daniel engaged with the gang's confrontational stance towards other prisoners and prison staff, he also drew on his experience as a soldier and always tried to stay clear of conflicts with guards: 'When the hierarchy is screaming at you, keep calm'. Daniel's experience shows how growing up in an over-penalized neighbourhood gives insights into ways to take part in the power relations at play within prison institutions. As such, it resonates with a central discussion in the anthropology of confinement concerning the weight that should be attributed to the specificities of power relations within sites of confinement, on the one hand, and the pre-carceral experiences of prisoners, on the other.

\section{Prisons as closed institutions or sites of passage?}

As prison ethnography developed in North America in the 1930s and 1940s, its pioneers often studied places of confinement in a similar fashion to their colleagues in anthropology departments, as small homogenous societies that had developed their own distinct rules and hierarchies in relative isolation. Whether one set foot on a sunny beach in the Pacific or entered the dark corridors of a Chicago prison, one was to study the values and ways of a group of persons (Rhodes 2001), or, in the words of an early prison ethnographer, 'the folkways, mores, customs, and general culture of the penitentiary' (Clemmer [1940] 1958: 299).

In contrast to most of their colleagues in the anthropology departments of the time, prison ethnographers already paid close attention to acts of conformity and of contestation to the power relations at play and to the processes by which hierarchies were created and undone within the 'Prison Community' (Clemmer [1940] 1958), the 'Society of Captives' (Sykes 1958) or 'Asylums' (Goffman 1961), to name but a few of the most important studies. In parallel to Chicago ethnographers' analysis of the 'assimilation' of immigrants into US society, these prison ethnographies showed how time behind bars modifies the attitudes of prisoners, leading to their interiorization of values and ways of doing that were considered specific to the (sub)cultures of the institution. With their focus on the ways in which prisoners cope with the deprivations they face, and how they take an oppositional or participatory stance to prison staff, these researchers all shared the assumption that prison subculture is a product of the institution itself, which often led to the assessment of prisoners-inthe-making as though they were 'tabula rasa', subjects with no past.

John Keith Irwin, who became a sociologist after his release from the prison of Soledad, argued, with fellow sociologist Donald Cressey, that the prison subculture that prisoners adapted to was not unrelated to - and should actually be analysed 
as - prisoners' former social environment, and that the behaviour of prisoners and their oppositional stance to the prison institution was influenced by their experiences prior to incarceration, notably their involvement in the subcultures of the street (Irwin and Cressey 1962).

Such focus on the pre-carceral experiences of prisoners grew with the exponential rise of incarceration of men and women from socially marginalized and economically disenfranchised neighbourhoods in the US and in Europe, especially related to the drug economy. Sociologist Gilles Chantraine's sociology of prison experiences shows that many first-time prisoners experience incarceration as a 'shock' or a brutal rupture with their lives before prison. Prisoners who grew up in over-incarcerated neighbourhoods in France, by contrast, experience a continuity between their life outside and inside prison, and many get caught in a 'downwards spiral' of substance abuse and continuous incarcerations and releases to the street, only to be re-incarcerated (Chantraine 2004). Manuela da Cunha's studies of the effects of drug enforcement on men and women from economically disenfranchised neighbourhoods in Portugal stress how whole populations have become interchangeable in a 'closed circuit' of persons who enter and exit prisons on a regular basis, sometimes as prisoners, sometimes as visitors to their incarcerated kin or peers. In spite of having never been imprisoned themselves, prisons are part of their social world, and like Daniel, they have acquired knowledge about the functioning of the institution from their neighbourhood. As such, approaching prisons as 'worlds apart' has produced an 'analytical dead angle' that is inadequate to understand the constant flows of persons in and out of prison (Cunha 2008).

Concerning the prison experiences of foreign nationals specifically, I have argued elsewhere that there are major differences in the prison socializations of first-generation undocumented migrants, who had migrated to France and the USA as adults, and the 1.5 generation, who had been socialized in the penalized neighbourhoods of these two metropolises (Boe 2016, 2018, 2020). The first experiences of incarceration of most undocumented migrants were very similar to those, described in the literature, of citizen prisoners who had no previous knowledge of prison. Most first-generation undocumented migrants had never expected to go to prison and experienced incarceration as a 'shock' (Chantraine 2004). However, they adapted to the workings of the prison institution very quickly, as compared to citizen prisoners, a phenomenon that I link with their pre-carceral experiences of having to stay discrete in public space to avoid police controls and of asymmetrical relations of power in the informal labour market (Boe 2016), and which can be compared to Daniel's army experience, of having learnt to 'stay calm when the hierarchy screams at you'. In contrast to first-generation migrants who arrived as adults, the 1.5 generation had knowledge of power relations within prison walls, and of how they could gain support from peer networks 'on the inside.'

Though the prison experiences of the 1.5 generation who had arrived in France and in the USA as children were no different from those of their citizen peers, being ordered deported came as a 'shock' to them, and altered their experiences of confinement. Foreign nationals who had been socialized as citizens and who 
never paid much attention to their nationality suddenly 'awoke to a nightmare', to borrow the expression of Roberto Gonzalez and Léo Chavez (2012) to characterize the situations of 1.5 generation migrants in the USA, who discover that they are undocumented when they become adults. Due to their new condition as illegalized subjects, they frequently encounter nation-state borders that are reproduced throughout the interior of migrant-receiving states (De Genova 2002). Those who are 'banished but undeported' (Boe 2018) have to learn to adapt to being illegalized migrants, notably by keeping a low profile to avoid the domestic border zones created by immigration enforcement (Boe 2008, 2016, 2018). Staying in the streets they grew up in represents a new danger, no longer only that of arrest and a prison sentence, but also of being detained and deported.

For foreign nationals with a deportation order, the 'closed circuit' between the streets and the prison now extends to new sites of confinement.

\section{When the neighbourhood meets again in immigration detention}

Foreign nationals of the 1.5 generation from penalized neighbourhoods no longer only meet their peers from the streets behind prison bars. Those who are caught up in deportation processes are transferred to immigration detention centres, often located far away from their neighbourhoods. Still, it is not unusual for fellow Brooklynites, for instance, to meet again in locations as far away as Louisiana. One afternoon in 2007, as we were having sodas in a Bed-Stuy diner, Daniel suddenly stood up and called out to a man who just entered:

Hey! They let you out! Lookin' good, man! I'm doing an interview here. This is Carolina from Paris, she works on deportations and prisons, this is Eric, he's a veteran outta Brooklyn too, we met at Oakdale.

Like Daniel, 'Eric' had been recruited for Operation Desert Storm. While they had only known of one another growing up in Brooklyn and during their army days, both were detained after an incarceration related to their addictions to drugs, triggered by war-induced PTSD. At the immigration detention centre of FDC Oakdale, in Louisiana, thousands of miles away from their neighbourhoods, they met many other immigration detainees from penalized neighbourhoods in New York and New Jersey. They soon discovered that numerous other foreign national army veterans had initially been recruited with the promise of citizenship, but had ended up being ordered deported instead.

FDC Oakdale is characteristic of the expansion of the private prison and immigration detention industry during the 1980s and 1990s, which was justified by cost savings. These savings, however, benefitted the corrections industry itself and its network of politicians more than they did taxpayers. A 1996 report from the US Accounting Service (GAO) even stressed that the use of private prisons was less cost-efficient than the use of public or state prisons. Furthermore, the savings came at a high price, as they often led to human rights violations, when corporate prison 
managers made savings on food, hygiene, cleaning, air-conditioning, heating, blankets, prison uniforms, and on the training of guards and other personnel (Dow 2004: 10; Patel and Jawetz 2007). Medical staff reported that they were encouraged to cut corners, including through savings on medicine and health care, their patients getting teeth pulled rather than fixed, for example (Dow 2004: 102-103).

Daniel and Eric soon experienced how FDC Oakdale suffered from all the ills of privately run facilities. They were detained at the same time as 'Michael', a Jamaican national who had been arrested for possession of marijuana, also in Brooklyn, before he was transferred to Oakdale. I met Michael once he had been released back to New York, where he had become involved in the legal case work of foreign nationals who were still detained, using the skills he had developed as a jailhouse lawyer to help others from the outside.

The three witnessed the consequences of medical shortcomings when a fellow New Yorker and detainee died in detention. Richard Rust was a 34-year-old Jamaican national who had been raised in Brooklyn and had been ordered deported after the passing of the retroactive 1996 laws for a crime that he had already served a sentence for a decade earlier. Rust had been detained and transferred to FDC Oakdale, several thousand miles away from his family and two children. Here, the young man suddenly collapsed one day and the ambulance came forty minutes later, by which time it was already too late. Michael, who witnessed Rust's death, told me in 2007:

And what happened was when he died, a lot of detainees were mad about it because of the response time. They tried to say that he died on his way to the hospital, but he died there. Because when he was leaving they covered his face. Why cover a person's face if he's alive, you understand what I'm saying? People ain't stupid. But they said he died on his way to the hospital. What happened, a lot of guys showed their anger.

Daniel was one of these detainees. For once, he did not stay calm but explained how Rust's death was 'the last drop' for himself and for many fellow detainees:

The whole system is so so so twisted, so messed up, so terrible... ... I mean, young guy had a heart attack. Took the officers a good twelve minutes to get to him. The guys went and said 'Guy's having a heart attack. The CO took his cool time to get there. He called medical. Other officers runnin' over. But none of them would touch him until the medical staff came. And then medical staff came. And she came with no equipment. She went running back to the medical office now, which is a little distance. By that time, one of the recreation supervisors attempted to perform CPR, but he didn't know what he was doing. It took the ambulance forty minutes to get there. By the time they came, he was dead. We almost had a riot after that. We all said: Fuck it! We're not going back to the houses. We stand in the yard, we're gonna hold a protest!

The administration at Oakdale quickly provided agents with riot helmets, pepper sprays, clubs and ski masks that made it impossible to recognize individual agents and file a complaint with their superiors. 
Michael, in contrast to Daniel, made sure not to take part in the protest. By then, he had been detained for five years while fighting his deportation case through legal strategies. Time is as central to the experience of confinement as is space (Boe 2020), and spending all those years in immigration detention had taught Michael to be careful. Fighting back, Michael thought, would bring retaliation from prison officials, but would actually also prevent detainees from fighting their legal cases against deportation, as he told me during an interview in 2007:

Because what happened, the guys in there started protesting, they didn't wanna go back in their cells, and that's in the government line, in the prison officials' line. It is to the government's advantage because they just call in the riot squad. You know what I'm saying? They locked up a lot of detainees for the riot. A lot of them stayed in the box (solitary confinement) until they were deported. Some even lost their case because they were in the box, you know? And that's why... I was being selfish for me, you know what I'm saying? Because if I ended up participating in that situation, maybe I wouldn't be here. I was thinking of myself. And between you and me, I would have died in Jamaica, if they'd sent me back.

Michael also knew that members of Families For Freedom were in Oakdale that day, to visit their detained family members. They contacted Rust's family in New York and mobilized the media (see also Kateel and Shahani 2008). Michael chose to bide his time and stay discrete while consulting law libraries and getting help from the human rights clinic of a university in New York. He still had hope that he might win his legal case and could not afford to spend time in solitary confinement.

Though he retrospectively insisted that he had been 'selfish' for his own sake, because he feared that participating in the riot might lead to solitary confinement and prevent him from fighting his deportation through legal strategies, his actions ended up having positive repercussions for other detainees than himself:

What happened, I wrote a letter, and got a petition signed about it and I slipped it to (a network of lawyers and non-profits), that's how I got it out. It ended up being a big story. And Congress made a law that in case of the death of a detainee, it's supposed to be investigated by an outside party, an unbiased investigation. Uhm... The guys in there were cursing me, saying: 'Why are you not protesting!' I know it seems cold, but what I was saying was that's not the way to do it. One thing with... When they say that 'sometimes the pen is stronger than the sword', it's really true because if I did act like the guys there, maybe the story wouldn't have come out, you understand what I'm saying? So... that's why I did it the way I did it.

As a result, eleven representatives demanded a full investigation into the death of Richard Rust and the access to medical care for detainees. They wrote:

We are equally troubled by the report that detention officials subsequently retaliated against a number of detainees who were friends of Mr Rust or upset over his death by sending them to disciplinary segregation where some were forced to remain for three months. (House Judiciary Committee, quoted in Kateel and Shahani 2008: 275) 
In this case, Michael's actions ended up making his conditions of detention and those of other detainees known. The responses of most detainees were tactical and not strategic (De Certeau 1980); they answered with bie, and not with mètis, as Michael did. Mètis combines flair, creativity, pragmatism, opportunism and the capacity to think ahead when accommodating the unexpected, and being able to recognize the right moment, kairos, or sudden opportunity, when it presents itself (Détienne and Vernant 1974). Michael's strategy might not have worked so well if Daniel, Eric and others hadn't rioted and exposed themselves to retaliation from the detention centre's riot squad, which, in turn, spurred media attention through the actions of activists, concerned citizens and politicians on the 'outside'.

\section{Rachid's closed circuit - Paris, immigration detention and the Fresnes prison}

Rachid's trajectory resembles that of Daniel in many ways. He too went from being a legal resident to becoming de-legalized in the country in which he grew up, experiencing broken promises of citizenship, and forced circulations between sites of confinement. Rachid is the oldest of six siblings, and the only one who was not born in France but in Tunisia. He arrived as a toddler in Paris with his mother in the late 1960s, through family reunification with his father who had been recruited, like many other North Africans, into France's manual workforce. Rachid once explained that growing up he had been more of a follower than a leader, that he was a 'weak kid' (his sister called him 'sensitive'), who found comfort in school work and was considered a nerd by many peers in his neighbourhood. The school's promise of equal opportunities for all was broken, as Rachid saw it, when his school principal refused to recommend him for higher education and pushed him to choose a career in manual labour, in spite of his good grades and ambition to continue studying. A misdemeanour brought him before the judge, and his chances of getting naturalization as a French citizen were over. Like many other foreign national delinquents, Rachid was de-legalized after the passing of the Pasqua laws in the 1990s, which blended security issues, anti-terrorism and anti-drug measures with deportation.

When the 1995 Paris métro bombings by Algerian organization 'Armed Islamic Group' (GIA) proved to have been carried out by Algerian-born but French-bred Khaled Kelkal, the media and leading politicians exposed him as 'a youth delinquent from the suburbs' who had gone into Islamic terrorism (Deltombe and Rigouste 2005: 195). This provided the Minister of Interior at the time, Charles Pasqua, with further arguments to pass new laws that strongly increased the possibilities to illegalize and deport even long-term resident foreign nationals convicted of misdemeanours and crimes (Mathieu 2006: 195). Most, if not all, foreign nationals who were ordered deported after the passing of these anti-terrorist laws had in fact been convicted of minor immigration offences or drug-related misdemeanours. Many of them were 1.5 generation migrant youths and young adults, and as the Pasqua laws on naturalization also made it more difficult for the children of immigrants to 
obtain French nationality, tens of thousands were ordered deported. Most would try to re-enter France clandestinely, as illegalized migrants, where they became targets of immigration enforcement with the creation of quotas for deportation in the early 2000s (Boe 2016).

Rachid succeeded in staying 'undeported' for ten years after he got his first deportation order, and like countless others, he entered and exited prisons, detention centres and his neighbourhood on a regular basis. For years, Rachid avoided deportation by self-mutilating just before he was released from prison, always choosing the right moment to swallow items or cut himself. Like other deportees, he was able to purchase razor blades through the prison's underground economy, wrap them in scotch tape and swallow them in order to pass security gates. He knew from experience when to find the right moment to make himself vomit in order to have the blade ready to injure himself and avoid deportation. Johanna Siméant (1998), who studied the French immigrant rights movement, shows how self-injuring, notably through hunger strikes, was a strategy to avoid deportation that deportable migrants 'on the outside' learnt through the experiences of those who had been in prisons. As Peter Nyers (2003) and Nicolas Fischer (2017) have convincingly argued, deportees can create situations through self-mutilations where they reverse the relations of power, as they force state actors to engage in negotiations over their rights to stay in a country. By simultaneously provoking and exposing the violence of the law and of the police officers who might attempt to dislodge them, they sometimes manage to transform their body into a 'sanctuary space. In this sense, strategic self-mutilations much resemble rioting. Daniel, Eric and others simultaneously provoked the physical violence of the riot squad and the solitary confinement measures, which in turn exposed state violence to activists, concerned citizens and politicians.

By doing everything he could to stay in France, Rachid, similarly to Michael who also 'bided his time', hoped to experience a change of deportation law spurred by an ongoing campaign that involved activists from church and immigrant rights groups during the late 1990s and early 2000s (Mathieu 2006). It led to a change of law in November 2003, opening the possibility for relief for foreign nationals who could prove that they had migrated to France before the age of thirteen and had never left the country for more than six months. Rachid and I were able to obtain his relief from deportation in 2005, over a year after our conversation in the corridor of the Fresnes prison, mentioned at the start of this article. For the first time, he was not fetched for deportation on his release from prison. Some days later, I met him on my way home from work, freshly released and determined not to go back to jail, having moved back in with his mother in the housing project where he had grown up, a few streets from where I was living at that time. However, only a couple of weeks had passed when Rachid's sister called me to tell me that he had started using again, had been arrested by the police and brought back to Fresnes. Though Rachid could no longer be deported, the 'downwards spiral' of continuous street-level drug addiction led him to accumulate countless other prison sentences and releases, much like Daniel in New York. 
As a lawyer, ethnographer and neighbour, I often met street-level drug users who told me that one of our mutual acquaintances had 'disparu du circuit' ('disappeared from the circuit'), when no-one seemed to have heard from them for a few months or years. A few among the 'disappeared', I later learnt from their families, friends or even from themselves, had managed to overcome their addiction, temporarily or permanently, often thanks to life-altering changes, such as the arrival of a child or the possibility to move away from their neighbourhood. Many never came back, but died prematurely from overdosing, often after a release from prison, or from accumulated health problems (Kokoreff, Coppel and Peraldi 2018).

Four years and two incarcerations after we had first met in 2007, Daniel had moved to a new location, far from Bed-Stuy, and came to fetch me at the station, smiling, having gained weight, wearing a custom-made cap saying: 'This veteran is medicated for your protection. He had been enrolled in a veteran programme that focused on his PTSD and addictions, and struggled with evictions, with not being able to pay his electricity bills in a flat located outside of New York, while being sure that he hadn't seen the last of Rikers. In 2011, looking back on a decade of successive incarcerations, Daniel still called Rikers his worst nightmare. He had started to keep his distance from the gang and the blind allegiance that its members expected from one another: 'I'm too old for that shit. Get stabbed for what? For someone I don't even know?'. The prison conditions, however, still affected him as much as they had during his first incarceration:

My worst nightmare. Besides getting deported. For real. ... Our human being status is just... they just snatch it away from you. You know, you walk in there, it's like, you're not a human being anymore. You're a thing. You're a number. You know. You're complete degraded, complete. I can't see nothin' worse, you know. And they have the nerve to talk about other countries. Aw, man, they need to go to Rikers Island and do some investigatin'. Before you start talkin' about China and Iran and... Bullshit! What we are doin' to our people!

Having made the argument that the neighbourhood can prepare someone for prison, it is also important to stress that even those who had previous insights into the workings of prison institutions, like Daniel or Rachid, and who have now been incarcerated and detained more times than they can remember, still suffer from the deprivations of confinement. Even though they have developed mètis and have succeeded in avoiding deportation for years, sometimes decades, their forced transits through sites of confinement have not left them unharmed. As I write these lines, Rachid has disappeared from the circuit, as have Michael and Eric. Daniel is currently hospitalized, struggling with poverty and cancer.

\section{Conclusion: going through prison and deportation}

A central discussion in the anthropology of confinement, which was briefly outlined in this article, has been over the weight that should be attributed to the 'outside' (the pre-carceral life of prisoners) and the 'inside' (their adaptation to an institution 
that allegedly differs greatly from the rest of society). Anthropologist Manuela da Cunha's argument that approaching prisons as 'worlds apart' produces an 'analytical dead angle' that is inadequate to understand the constant flows of persons in and out of prison (Cunha 2008) is just as relevant now, as prison and penalized neighbourhoods spill into new realms. After 'going through' prison, the 'undeported' were routinely detained, released and incarcerated or detained again. In this sense, 'going through prison' signals both the experiences of institutions of confinement as sites of passage and the hardships created by the institutions themselves, as well as the changes in immigration law and practices. The combined wars against drugs, terror and immigration have brought an additional dimension to the trajectories of the 1.5 generation, who, in contrast to their citizen peers, can be forcibly deported to their countries of citizenship or transferred to immigration detention.

When the populations of one site of confinement spill into the other, so do strategies and knowledge travel across sites. As they 'traversed sites of confinement' (Jefferson 2010: 387), the protagonists of this article, like the many other 'undeported' I have met within and outside prisons and penalized neighbourhoods, learnt and reproduced how to fight back collectively or individually through self-mutilating, hunger striking, the mobilization of the law as jailhouse lawyers, adhering to gangs or other peer groups, rioting or spurring media attention through alliances with activists or lawyers. However, through their trajectories in different sites of confinement, they not only learnt practices of contestation but also learnt how to outwardly comply while biding their time, waiting to choose the proper moment to act in specific ways that could be to their own advantage, and sometimes to that of others. In order to understand the ways in which they accumulated experience, which they acquired in different sites of confinement and reproduced in others, I mobilized the concept of mètis, to explain the ways in which individuals adapt to shifting, uncertain situations, but are also (sometimes) able to challenge and change these circumstances.

Marcel Détienne and Jean-Pierre Vernant (1974) argue that the central question for the Greek is whether Troy will fall through the use of mètis or that of bie - by cunning intelligence or by brute strength. The answer, of course, is by mètis, which is the quality of a certain type of hero. Ulysses distinguishes himself by wrestling and winning over the hero Ajax in spite of Ajax's greater physical strength, and he demonstrates his cunning and sense for strategy as he designs the Trojan horse or as he outsmarts powerful adversaries such as the Cyclops. Détienne and Vernant show how Ulysses 'was praised for having mètis in abundance,' 'improvising tactics to get his men out of one tight spot after another', drawing on his 'ability to adapt successfully to a constantly shifting situation' and a 'capacity to understand, and hence outwit, his human and divine adversaries' (Scott 1998: 313). In spite of the constant metamorphosis of his surroundings, Ulysses never loses his capacity to think ahead when accommodating the unexpected and adapting constantly to ever-shifting situations, recognizing the right moment when it presents itself. Having mètis implies being able to recognize the right moment, kairos, or sudden opportunity when it presents itself (Détienne and Vernant 1974). Mètis, then, is a type of intelligence 
or a mental attitude that combines flair, creativity, pragmatism, opportunism and the wisdom of experience. The more practical skills one has, the more likely one is to get safely through troubled waters and to know how to sail against the wind. As a sailor, Ulysses had experience of shifting seas and knew how to adapt when the Gods brought high waves, tempests or no wind.

The experiences of the undeported have shown some of the limits of the sailing metaphor of 'social navigation. With a focus on how agents seek to steer a course rather than drift astray (Vigh 2010: 158), social navigation implies that the individual has no impact on the social forces that constrain or enable different forms of behaviour. The wind, the elements, are not for a sailor to change. Ulysses again serves as a good example. Not only was he able to adapt successfully to the whims of the Gods, sometimes even outwitting them, but his actions also contributed to influence the next actions of the Gods. The use of mètis and bie, then, recognizes not only how individuals adapt to social forces that confine or move them, but makes it possible to account for the changes that an individual can bring to bear on larger social forces.

As they traverse sites of confinement and are able to avoid deportation, the undeported not only 'navigate' systems, but they can push for social change regarding immigration law or deportation practices. This was the case when the actions of 'the undeported' influenced the US Congress or when the French government reformed immigration law. These 'weapons of the weak', however, work best through alliances with influential citizens, which are difficult to build when one is isolated in the 'closed circuits' created by the entanglements of criminal justice and immigration law.

\section{Acknowledgements}

I thank the real 'Rachid,' 'Michael,' 'Eric' and 'Daniel' for their participation in this work over the course of several years. I am also grateful to the Independent Research Fund Denmark for funding the writing of this article and to my two hosting institutions, IMC, Aarhus University and Université de Paris, CERLIS, CNRS. Thank you to three great editors, Julienne Weegels, Tomas Martin and Andrew Jefferson, and to the anonymous peer reviewers for their careful reading and constructive comments that helped clarify the argument and improve the article. I dedicate it to 'Daniel', who kindly read the article, said that he liked it, and asked all readers to let those around you know that foreign national army veterans, who were promised citizenship, are still being deported from the USA today. 
Carolina S. Boe, Ph.D., is a sociologist and anthropologist. She is currently an Independent Research Fund Denmark post-doctoral fellow at IMC, Aarhus University and at Université de Paris, CERLIS, CNRS. Her research centres on the anthropology of confinement, deportation, illegalization and bordering practices in urban spaces, primarily in France and the USA. She has worked for nonprofit organizations in these fields, including Cimade, American Friends' Service Committee, Cette France-là, and the Prison Litigation Network.

\section{Note}

1. All names have been altered, in accordance with the wishes of the real 'Rachid', 'Michael,' 'Eric' and 'Daniel'.

\section{References}

Boe, C. 2009. 'Coopération publique, résistance cachée : étrangers incarcérés en France', in: C. Kobelinski and C. Makaremi (eds.), Le Confinement des étrangers en Europe : Perspectives de Terrain, Editions du Croquant.

Boe, C. S. 2016. 'From Banlieue Youth to Undocumented Migrant: Illegalized ForeignNationals in Penal Institutions and Public Space. Criminology \& Criminal Justice 16 (3): 319-336. doi:10.1177/1748895816650480.

Boe, C. S. 2018. 'Banished Yet Undeported'. In D. Brotherton and P. Kretsedemas (eds), Immigration Policy in the Age of Punishment: Detention, Deportation and Border Control. New York: Columbia University Press.

Boe, C. S. 2020. The Undeported: The Making of a Floating Population of Exiles in France and Europe. Lanham, MD: Rowman and Littlefield.

Boe, C. S. and N. Fischer. 2010. 'Lethnographe en milieu fermé: Deux enquêtes sur les étrangers en prison et en rétention administrative face à l'expertise associative et aux enjeux de la publication'. In S. Laurens and F. Neyrat (eds), Enquêter: de quel droit? Menaces sur l'enquête en sciences sociales. Bellecombe-en-Bauges: Le Croquant.

Bourgois, P. 2002. In Search of Respect: Selling Crack in El Barrio. Cambridge: Cambridge University Press.

Brotherton, D. and L. Barrios. 2011. Banished to the Homeland: Dominican Deportees and Their Stories of Exile. New York: Columbia University Press.

Chantraine, G. 2004. Par-delà les murs: Experiences et trajectories en maison d'arrêt. Paris: Presses Universitaires de France.

Clemmer, D. (1940) 1958. The Prison Community. New York: Holt, Rinehart \& Winston.

Contreras, R. 2012. The Stickup Kids: Race, Drugs, Violence, and the American Dream. Berkeley: University of California Press.

Coutin, S. B. (2016) Exiled Home. Salvadoran Transnational Youth in the Aftermath of Violence. Duke University Press.

Cunha, M. 2008. 'Closed Circuits: Kinship, Neighborhood and Incarceration in Urban Portugal'. Ethnography 9 (3): 325-350. doi:10.1177/1466138108094974.

De Certeau M. (1980) 1994 L'invention du quotidien Tome 1 Arts de faire. Paris : Gallimard. 
De Genova, N. 2002. 'Migrant Illegality and Deportability in Everyday Life'. Annual Review of Anthropology 31: 419-447. doi:10.1146/annurev.anthro.31.040402.085432.

De Genova, N. and N. Peutz (eds). 2010. The Deportation Regime: Sovereignty, Space and the Freedom of Movement. Durham, NC: Duke University Press.

Deltombe, T. and M. Rigouste. 2005. 'L'ennemi intérieur: la construction médiatique de la figure de l'Arabe'. In P. Blanchard, N. Bancel and S. Lemaire (eds), La fracture coloniale: La société française au prisme de l'héritage colonial. Paris: La Découverte, 191-198.

Détienne, M. and J. P. Vernant. 1974. Les ruses de l'intelligence: La mètis des Grecs. Paris: Flammarion.

Dingeman-Cerda, K. and R. Rumbaut. 2015. 'Alienation in Salvadoran Society'. In D. Kanstroom and M. Brinton Lykes (eds), The New Deportations Delirium: Interdisciplinary Responses. New York: New York University Press.

Dow, M. 2004. American Gulag, Inside U.S. Immigration Prisons. Berkeley: University of California Press.

Duprez, D. and M. Kokoreff. 2000. Les mondes de la drogue: Usages et trafics dans les quartiers. Paris: Odile Jacob.

Fischer, N. 2017. Le territoire de l'expulsion: La rétention administrative des étrangers dans l'Etat de droit. Lyon: Presses de l'ENS.

Foucault, M. 1979. Discipline and Punish: The Birth of the Prison. London: Penguin.

Goffman, E. 1961. Asylums: Essays on the Social Situation of Mental Patients and Other Inmates. London: Anchor Books.

Gonzales, R. G. and L. R. Chavez. 2012 “'Awakening to a Nightmare”: Abjectivity and Illegality in the Lives of Undocumented 1.5 Generation Latino Immigrants in the United States'. Current Anthropology 53 (3): 255-281. doi:10.1086/665414.

Irwin, J. and D. R. Cressey. 1962. 'Thieves, Convicts and the Inmate Culture', Social Problems, 10 (2): 142-155.

Jefferson A. M. 2010. 'Traversing Sites of Confinement: Post-Prison Survival in Sierra Leone'. Theoretical Criminology 14 (4): 387-406. doi:10.1177/1362480610370832.

Jobard, F. 2010. 'Le gibier de police immuable ou changeant?' Archives de politique criminelle 32 (1): 93-105. https://www.cairn.info/revue-revue-francaise-de-sciencepolitique-2016-2-page-271.htm.

Kateel, S. and A. Shahani. 2008. 'Families for Freedom: Against Deportation and Delegalization' in Brotherton, D. and P. Kretsedemas (eds). Keeping Out the Other: A Critical Introduction to Immigration Enforcement Today. New York: Columbia University Press, 258-288.

Kokoreff, M., A. Coppel and M. Peraldi. 2018. La catastrophe invisible: Histoire sociale de l'héroïne (France, années 1950-2000). Paris: Éditions Amsterdam.

Lee, J. 1981. 'Some Structural Aspects of Police Deviance in Relations with Minority Groups'. In C. Shearing and P. Stenning (eds), Organizational Police Deviance: Its Structure and Control. Toronto: Butterworths, 49-82.

Mathieu, L. 2006. La double peine. Histoire d'une lutte inachevée, Paris: La Dispute.

Morawetz, N. 2000 'Understanding the Impact of the 1996 Deportation Laws and the Limited Scope of Proposed Reforms', Harvard Law Review 113 (8): 1936-1962.

Nyers P. 2003. 'Abject Cosmopolitanism: The Politics of Protection in the AntiDeportation Movement', Third World Quarterly 24 (6): 1069-1093. 
Patel, S. and T. Jawetz. 2007. 'Detention and Deportation Working Group: Materials Submitted to the United Nations Special Rapporteur on the Human Rights of Migrants.' https://www.ohchr.org/Documents/Issues/Migration/InSearchofDignityOHCHR_Report_HR_Migrants_at_Europes_Borders.pdf.

Rhodes L. 2001. 'Toward an Anthropology of Prisons'. Annual Review of Anthropology 30: 65-87. doi:10.1146/annurev.anthro.30.1.65.

Scott, J. C. 1998. Seeing Like a State: How Certain Schemes to Improve the Human Condition Have Failed. New Haven, CT: Yale University Press.

Siméant, J. 1998. 'Lefficacité des corps souffrants: Le recours aux grèves de la faim en France’. Sociétés Contemporaines 31: 59-85. doi:10.3406/socco.1998.1771.

Sykes, G. 1958. The Society of Captives: A Study of a Maximum Security Prison. Princeton, NJ: Princeton University Press.

Vigh, H. 2009. 'Motion Squared: A Second Look at the Concept of Social Navigation'. Anthropological Theory 9 (4): 419-438. doi:10.1177/1463499609356044.

Vigh, H. 2010. 'Youth Mobilisation as Social Navigation. Reflections on the concept of dubriagem'. Cadernos de Estudos Africanos, 18/19, 140-164.

Zilberg, E. 2011. Space of Detention: The Making of a Transnational Gang Crisis between Los Angeles and San Salvador. Durham, NC: Duke University Press. 